\title{
The Identification of Chemical Compound and Antibacterial Activity Test of Kopasanda (Chromolaena Odorata L.) Leaf Extract Against Vibriosis-Causing Vibrio harveyi (MR 275 Rif) on Tiger Shrimp
}

\author{
Harlina (Corresponding author) \\ Faculty of Fisheries and Marine Science, Brawijaya University, Indonesian \\ E-mail: linausman1965@yahoo.com
}

Arief Prajitno

Faculty of Fisheries and Marine Science, Brawijaya University (Promotor), Indonesian

Eddy Suprayitno

Faculty of Fisheries and Marine Science, Brawijaya University (Co-Promotor), Indonesian

Happy Nursyam

Faculty of Fisheries and Marine Science, Brawijaya University (Co-Promotor), Indonesian

Received: February 13, 2013 Accepted: March 21, 2013 Published: July 1, 2013

doi:10.5296/ast.v1i2.3558 URL: http://dx.doi.org/10.5296/ast.v1i2.3558

\begin{abstract}
Kopasanda (Chromolaena odorata L.) R.M King and H. Rob were classified as blossoming bush species in the Asteraceae family. An empirical study showed that kopasanda ( $C$. odorata L.) leaf had been used by the embankment farmers at South Sulawesi Province to eradicate Vibriosis which caused death for tiger prawn (P.monodon Fabr.). The objective of research was to understand the bioactive compound that was contained within kopasanda $(C$. odorata L.) leaf extract and its antibacterial activity against $V$. harveyi. Result of
\end{abstract}




\section{Macrothink}

Aquatic Science and Technology

ISSN 2168-9148 2013, Vol. 1, No. 2

identification showed that the presence of phenolic, flavonoid, alkaloid, and steroid. Result of the extraction of $500 \mathrm{~g}$ kopasanda (C. odorata L) leaf powders with methanol solvent was producing $81.010 \mathrm{~g}$ methanol extracts. Its antibacterial test against $V$. harveyi indicated that there was an ability to prevent the growth of $V$. harveyi. The partition of $50 \mathrm{~g}$ methanol extract with ethyl acetate was resulting in 29,605 g ethyl acetate extract. The residue was partitioned with n-hexane which produced 9,575 $\mathrm{g}$ n-hexane. These three extracts were subjected to the test of antibacterial activity against $V$. harveyi. Result of antibacterial activity test showed that the methanol extract was producing the highest preventive zone, which was $19 \mathrm{~mm}$. It was followed by $9 \mathrm{~mm}$ from the ethyl acetate extract, while n-hexane extract did not show a preventive zone at all. The test indicated minimum inhibitory levels (MIC), supporting the conclusion that the kopasanda (C.odorata L.) leaf extract inhibited the growth of $V$. harveyi active with a minimum inhibitory concentration of $0,625 \mathrm{mg} / \mathrm{mL}$.

Keywords: Kopasanda (Chromolaena odorata L.) Leaf, Chemical compound, Antibacterial, Vibrio harveyi, Tiger Shrimp (Penaeus monodon Fabr.) 


\section{Background}

A main problem of the tiger shrimp cultivation, was a mass mortality due to disease attack. One such disease was considered as a serious problem, which caused by pathogenic bacteria infection, especially from vibrio genus, called Vibrio harveyi (Mariyono et al., 2002). These bacteria infect almost all cultivated marine organisms such as crustacean, mollusca and fish (Isnansetyo et al., 2009). Crustacean, including shrimp, crab, lobster and Artemia, very susceptible to this opportunistic pathogenic bacteria (Sunaryanto \& Maryam, 1986; Lavilla-Pitogo et al., 1992; Jivaranichpaisal et el., 1994; Karuna sagar et al., 1994; Liu et al., 1996; Robertson et al., 1998; Diggles et al., 2000; Soto-Rodriguez et al., 2003; and Bourne et al., 2007). Result of in vivo study indicated that $V$. harveyi was pathogenic to the post-larva stage (PL-14) of prawn in the density of $10^{7} \mathrm{CFU} / \mathrm{mL}$ (Khodriah et al., 2011).

A general way to deal with the vibriosis disease was using chemical and antibiotic substances (Brown, 1989). These substances, bacteria however have become resistent to these chemical which are, also harmful to the environment, and accumulate in shrimp which then influenced the quality of shrimp and become hazardous to the consumer (Defoirdt et al., 2007). As such. countries in European Union in recent years have implemented a zero tolerance to fishery product, including prawn (Fattah, 2008) treated with these chemicals harming Indonesian exports and calling for less harmful methods of treating vibriosis disease.

One proposed alternative is the use of kopasanda (Chromolaena odorata L.) leaf extract (Suryati and Gunarto 2001) due to hight levels of bioactive compound with natural antibacterial activity. Other uses for leaf extracts include healing injured skin and blood retainer (Anonymous, 2012). Other parts of the plant also have medicinal uses. For example the root is also useful as anti-pyretic and analgesic agents. The flower of the plant might be usable as insect poison (Anonymous, 2012). Research by embacment farmer in South Sulawesi suggest kopasanda plant control shrimp disease. (Suryati and Gunarto, 2001).

Here we report firstly the chemical properties and the antibacterial activity of kopasanda (C.odorata L) leaf extract against vibriosis-causing $V$. harveyi at post-larva stage of tiger shrimp examining the potential of kopasanda plant as the natural anti-bacterial substance in the elimination of vibriosis on tiger shrimp

\section{Material and Method of Research}

\subsection{Sampling and Identification of Kopasanda (C. odorata L.) Plant}

Kopasanda plant (C. odorata L.) were sampled from The Experiment Embankment Installation Area of Research Institute for Coastal Aquaculture, Maranak, Maros District, South Sulawesi, Indonesia in June 2012 (Figure 1). 


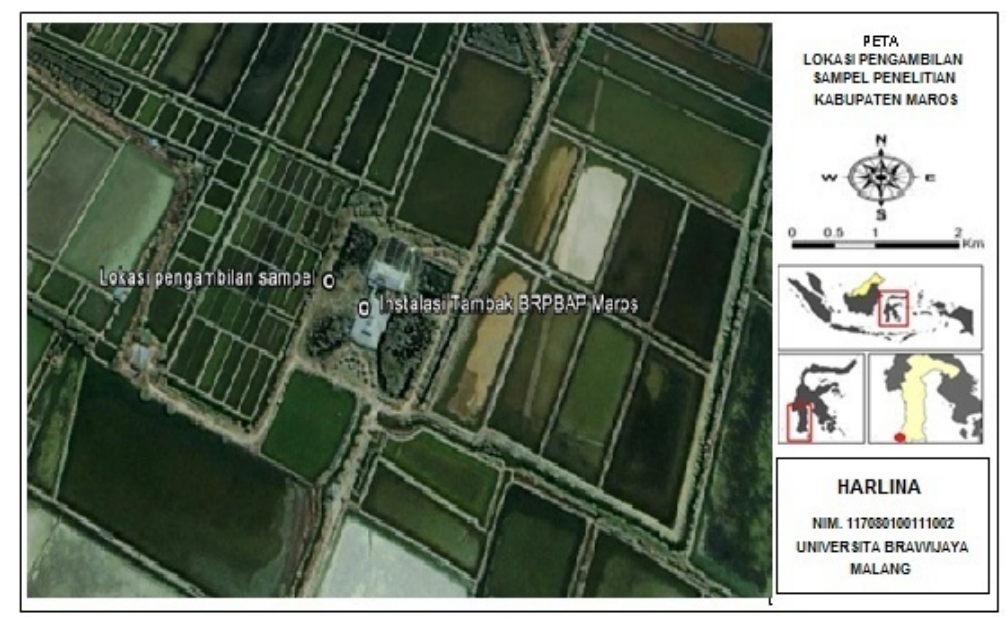

Figure 1. Sampling Location of Kopasanda (C. odorata L.)

Kopasanda (C.odorata L.) identification were confirmed at "Herbarium Bogoriense" Laboratory, Botanical Division of Research Center for Biology- Indonesian Institute of Sciences-Bogor Voucher No. 536/IPH.1.02/If.8/IV/2012. The speciment was stored there.

\subsection{The Preparation, Extraction and Partition of Kopasanda (C. odorata L.) Leaf}

Sample preparation was undertaken at the Biofarmaka Laboratory, Faculty of Pharmacy, University of Hasanuddin. Here, kopasanda leaf samples were washed through the flowing water and dried by aerating. 500 grams of kopasanda leaf powder was extracted by soaking the whole simplicia in $96 \%$ methanol solvent (MeOH) and incubating for $3 \times 24$ hours. Then, methanol extract and its dregs were separated. Liquid methanol extract from kopasanda leaf was vaporized to lift out methanol using rotary evaporator at $40^{\circ} \mathrm{C}$. The viscous methanol extract was then obtained and ready for antibacterial activity screening test. The dregs were dried and weighted to figure out its final weight. Moreover, 50 grams viscous methanol extract was partitioned into Solid-Liquid partition using n-hexane solvent to obtain n-hexane extract and residue. The residue was then partitioned again into Solid-Liquid partition using ethyl acetate solvent to produce ethyl acetate extract. Subsequently, these three samples of viscous extract (methanol, n-hexane, and ethyl acetate extracts) were tested for its antibacterial activity against $V$. harveyi using disc diffusion method (Bauer et al., 1966)).

\subsection{Phytochemical Test of Kopasanda (C.odorata L) Leaf Extract}

Phytochemical test was conducted to understand the bioactive compounds within kopasanda (C. odorata L.) leaf, which included phenolic, tannine, steroid, saponin, flavanoid, and alkaloid. The procedure to analyze each bioactive compound was as followed:

1) Phenolic Compound Test, $0.1 \mathrm{~g}$ of extract sample was dissolved into $1 \mathrm{ml}$ methanol. Few drops of $\mathrm{FeCl}_{3} 1 \%$ were given. The presence of phenol was understood by the color of purple, green and black (Wibowo et al., 2008; Chulet et al., 2010).

2) Tannin Compound Test, $\mathrm{FeCl}_{3}$ Test. 2 grams of sample were extracted with $5 \mathrm{ml}$ hot water. The extract was screened by cotton and moved into other tube. Two to three drops of 
$\mathrm{FeCl}_{3} 1 \%$ were added. The sample that was positively containing tannin would change its color into blackish green (IAEA, 2000; Chullet et al., 2010)

3) Flavonoid Compound Test

- Shinoda Test. The sample was dropped by alcohol and added by Mg powder, and dropped again with viscous $\mathrm{HCl}$. Flavonoid was shown through colors such as orange (flavon), red (flavonol), and purple (xanthon) (Wibowo et al., 2008; Arulpriya et al., 2010).

- NaOH Test: 2 grams of sample were extracted with $5 \mathrm{ml}$ methanol, screening the extract with cotton, moving it to other tube, adding 2 drops $\mathrm{NaOH} 10 \%$, and shaking it strongly. The sample would positively contain flavonoid if there was very salient color.

- $\mathrm{H}_{2} \mathrm{SO}_{4}$ Test: $2 \mathrm{ml}$ liquid methanol extract and viscous sulfate acid. The presence of flavonoid was shown by the colors of dark yellow, bluish red (chalcone, aurone), and red-orange (flavonon) (Wibowo et al., 2008; Arulpriya et al., 2010).

4) Saponin Compound Test

2 grams of each sample was extracted with $5 \mathrm{ml}$ hot water, screening the extract with cotton moving it to other tube, shaking it strongly and incubated for 2 minutes before 2 drops $2 \mathrm{~N}$ $\mathrm{HCl}$ were added. Strong shaking was given again to see whether the foam emerged after incubation for 10 minutes. The sample would contain saponin if the foam was highly intensive and consistent for 10 minutes.

\section{5) Alkaloid Compound Test}

- Mayer Test. $2 \mathrm{ml}$ of liquid methanol extract was added to two drops of Mayer reactant (reagent). Alkaloid was present by white precipitation. (Preparation of Mayer Reagent was involving two solutions. First was produced by dissolving $1.36 \mathrm{~g} \mathrm{HgCl}_{2}$ into $60 \mathrm{ml}$ aquades. Other solution was made by dissolving $5 \mathrm{~g} \mathrm{KI}$ into $10 \mathrm{ml}$ aquades. Both solutions were mixed and diluted to obtain $100 \mathrm{ml}$ volume) (Wibowo et al., 2008; Arulpriya et al., 2010).

- Dragendorff Test. $2 \mathrm{ml}$ of liquid methanol extract was mixed with ten drops of chloride acid or viscous sulfate acid. Two drops of Dragendorff reactant (reagent) was added, and the presence of alkaloid was shown by orange precipitation. (Preparation of Dragendorff Reagent also involved two solutions. One solution was produced by dissolving $8 \mathrm{~g} \mathrm{KI}$ with $20 \mathrm{ml}$ aquades. In other batch, $0.85 \mathrm{~g}$ bismuth sub-nitrate $\left(\mathrm{BiNO}_{3}(\mathrm{OH})_{2} \mathrm{BIO}(\mathrm{OH})\right)$ was dissolved into $40 \mathrm{ml}$ glacial acetate acid. Both solutions were mixed together and diluted to achieve 100 $\mathrm{ml}$ volume) (O’Brien et al., 1982; Wibowo et al., 2008).

- Wagner Test. $2 \mathrm{ml}$ of liquid methanol extract was mixed with two drops Wagner reactant (reagent). Brown precipitation indicated the alkaloid compound. (Preparation of Wagner Reagent was by dissolving $1.72 \mathrm{~g} \mathrm{I}_{2}$ dan $2 \mathrm{~g} \mathrm{KI}$ with $5 \mathrm{ml}$ aquades, and diluted to obtain 100 ml volume) (Wibowo et al., 2008; Arulpriya et al., 2010).

6) Terpenoid and Steroid Compounds Test

Lieberman-Burchard Test. $2 \mathrm{ml}$ of leaft sample was mixed with two drops 
Lieberman-Buechard Reactant (reagent). Terpenoid was shown by the presence of blue, red and purple colors. (Preparation of Lieberman-Buechard Reagent was involving viscous sulfate acid and anhydrate acetate acid. Both acids were stored in different batch/bottle) (Wibowo et al., 2008; Jagessar \& Cox, 2010).

Salkowski Test. $2 \mathrm{ml}$ methanol extract was mixed with $1 \mathrm{ml}$ chloroform and with $1 \mathrm{ml}$ viscous sulfate acid, thus producing two layers. Red or orange layer showed the presence of terpenoid and steroid compounds (Egwaikhide \& Gimba, 2007; Wibowo et al., 2008).

\subsection{Preparation of Vibrio harveyi}

Antibacterial activity was tested with pure culture of $V$. harveyi obtained from the isolation of Vibriosis-infected shrimp at Environmental Health Laboratory of Research Institute for Coastal Aquaculture (RICA) Maros District, South Sulawesi, Indonesia. The bacterial culture was prepared using the bacterial rejuvenation procedure (Rosmiati et al., 2011). This procedure involved some rejuvenation stages such as: (1) $5 \mathrm{ml}$ Nutrient Broth (NB) solution were prepared in the reaction tube; (2) V. harveyi bacteria pure culture was aseptically taken for 1 oce, and this culture was put into Nutrient Broth (NB) agar; (3) Bacteria-contained Nutrient Broth (NB) solution would be incubated for 24 hours at $37^{0} \mathrm{C}$; (4) After incubation for 24 hours, the bacteria in the Nutrient Broth (NB) agar were cultured again into solid media using Thiosulphate Citrate Bile Sucrose Agar (TCBSA), and incubated again for more than 24-48 hours at $25{ }^{\circ} \mathrm{C}$; and (5) After 24 hours, the bacteria were ready for antibacterial test.

\subsection{Antibacterial Potential Test of Kopasanda (C. odorata L.) Leaf Extract against V. harveyi}

The potential of kopasanda leaf extract as the antimicrobial substance was determined by weighting and dissolving $10 \mathrm{mg}$ kopasanda (C. odorata L.) leaf extract with $0.2 \mathrm{ml}$ DMSO. The dissolved extract was then given $9.8 \mathrm{ml}$ medium $\mathrm{MH}$ (Muller Hinton) to obtain the concentration of $1 \mathrm{mg} / \mathrm{mL}$ and subsequently poured into petri dish, and homogenized and solidified. $V$. harveyi suspension was then smeared onto already-solidified $\mathrm{MH}$ (Muller Hinton) medium, and this medium was incubated for $1 \times 24$ hours at $37{ }^{\circ} \mathrm{C}$. The growth of $V$. harveyi was then observed.

\subsection{Antibacterial Activity}

Antibacterial activity test employed the Kibry-Bauer Method (Bauer et al., 1966) using disc diffusion. Prior to testing, Vibrio harveyi inoculums were zig-zag streaked on TCBSA (Thiosulfat Citrate Bile Sucrose Agar) and incubated for 24 hours at $28^{\circ} \mathrm{C}$. One colony of the bacteria growth was sub-cultured in $50 \mathrm{ml}$ of nutrient broth medium (Sigma, FRG) and incubated for 4 hours using a shaker at $150 \mathrm{rpm}$ and $28^{\circ} \mathrm{C}$ to produce the density of $10^{7}$ $\mathrm{CFU} / \mathrm{mL}$ (Khodriah et al., 2011). Furthermore, $100 \mu \mathrm{L}$ of bacteria inoculum were spread on Mueller Hinton agar. The filter paper discs $(6 \mathrm{~mm}$ in diameter) were individually impregnated with $20 \mu \mathrm{L}$ of the extracts $(30 \mathrm{mg} / \mathrm{mL})$, dried in a laminar air flow and then placed onto the agar plates previously inoculated with the tested microorganisms. The plates were incubated at $30{ }^{\circ} \mathrm{C}$ for $24 \mathrm{~h}$. The diameters of the inhibition zones were measured in millimetres. All the tests were performed in triplicate. The antibacterial activity was then 


\section{Macrothink

interpreted as followed: The diameter of inhibition zone $\geq 15.0 \mathrm{~mm}$ was considered as strong; 10.0 to $14.5 \mathrm{~mm}$ as moderate and $<10 \mathrm{~mm}$ as weak (Habsah et al., 2007; Rosmiati et al., 2011).

\subsection{Determination of Minimum Inhibitory Concentration (MIC)}

The minimum inhibitory concentration (MIC) was the smallest antimicrobial concentration which prevented microscopic growth of bacteria. The minimum inhibitory concentration (MIC) of the ekstrast against $V$. harveyi was tested by using serial dillution. Ten (10) sterile reaction tubes were prepared. Kopasanda leaf methanol extract $(20 \mathrm{mg} / \mathrm{mL})$ was put into the first tube. The dillution of the extract was conducted from the second tube to the seventh tube, thus producing doses of $10 ; 5 ; 2.5 ; 1.25 ; 0.625 ; 0.313$; and $0.156 \mathrm{mg} / \mathrm{mL}$. Each tube received 1 oce of $V$. harveyi. The eighth tube received $\mathrm{NB}+V$. harveyi, the ninth tube accepted NB without $V$. harveyi, and the tenth tube accommodated NB+ kopasanda leaf extract. All tubes were vortexed and incubated in the incubator for 24 hours at $37^{\circ} \mathrm{C}$. After 24 hours, whole tubes were observed to compare the medium viscosity of test samples compared the positive and negative control. Each tube was inoculated into TCBSA (Thiosulfat Citrate Bile Sucrose Agar) solid and incubated for 24 hours. The prevention of growth indicated the lack of bacterial colony growth. The lowest dose that was able to prevent the bacterial growth was called Minimum Inhibitory Concentration (MIC).

\section{Result}

\subsection{Result of Extraction and Partition of Kopasanda (C. odorata L.) Leaf}

Result of Extraction and Partition of Kopasanda (C.odorata L.) Leaf was shown in Figure 2.

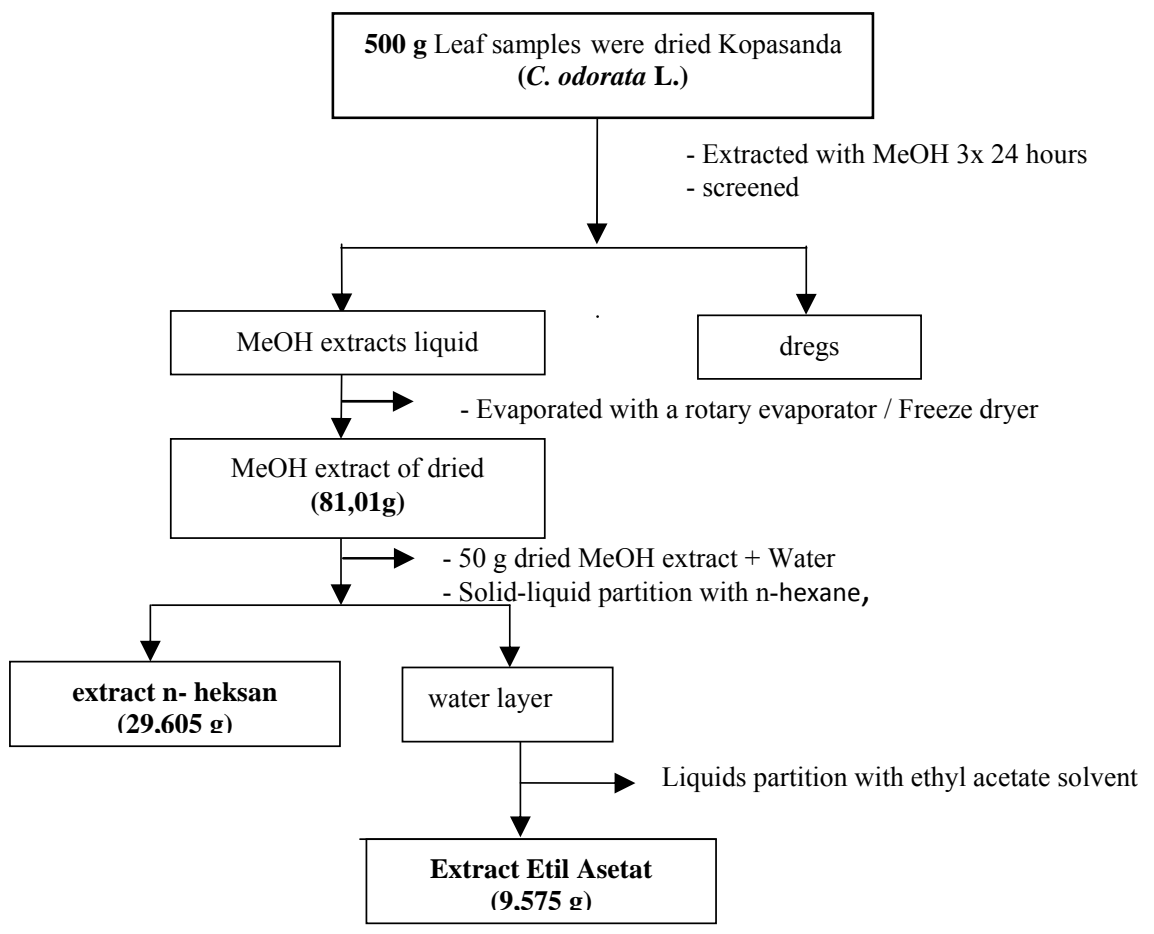

Figure 2. Extraction and partition path Kopasanda (C.odorata L) leaf 


\section{Macrothink}

Aquatic Science and Technology

ISSN 2168-9148

2013, Vol. 1, No. 2

3.2 Result of Phytochemical Test of Kopasanda (C. odorata L.) Leaf Extract

Result of quantitative test of bioactive compound in the kopasanda (C.odorata L.) leaf extract was shown in Table 1.

Table 1. Result of phytochemical test of active substance of Kopasanda (C. odorata L.) leaf

\begin{tabular}{|c|c|c|c|}
\hline No & Active Substance & Discoloration & Result \\
\hline 1. & Phenolic & Blackish green & + \\
\hline 2. & Tannin & None & - \\
\hline 3. & $\begin{array}{l}\text { Terpenoid and Steroid of } \\
\text { Lieberman-Buerchard Reagent }\end{array}$ & Green & + \\
\hline 4. & Saponin & No foam & - \\
\hline \multirow[t]{4}{*}{5.} & Flavonoid with reagents & & \\
\hline & $\mathrm{HCl}$ & Orange brown, purple & + \\
\hline & $\mathrm{H}_{2} \mathrm{SO}_{4}$ & Brown & + \\
\hline & $\mathrm{NaOH}$ & Salient green & + \\
\hline \multirow[t]{5}{*}{6.} & Alkaloid & & \\
\hline & Dragendorff Reagent & Red precipitation & + \\
\hline & Wagner Reagent & Brownish precipitation & + \\
\hline & Mayer Reagent & Cream precipitation & + \\
\hline & Hager Reagent & Yellow precipitation & + \\
\hline
\end{tabular}

3.3 Result of Antimicrobial Potential Test of Kopasanda (C. odorata L.) Leaf Extract against V. Harveyi

After testing the antibacterial potential against $V$. harveyi, it was obtained the result that was similar to that in Figure 3 and Table 2.

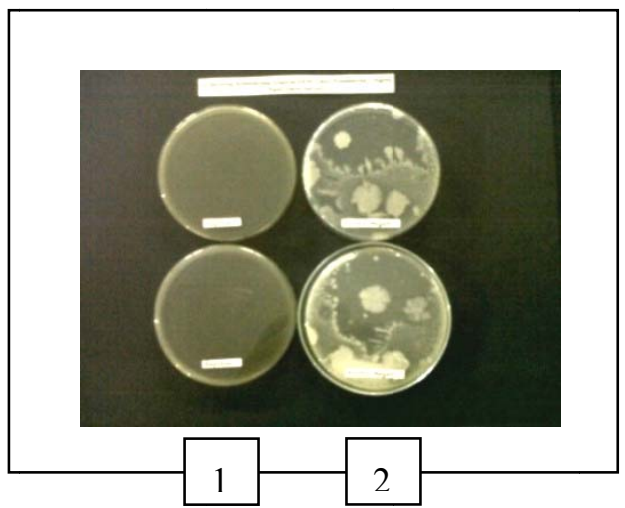

Particulars 1 : Treatment with kopasanda extract

2 : Treatment without kopasanda extract

Figure 3. Result of antimicrobial potential test of Kopasanda extract against $V$. harveyi 


\section{Macrothink}

Aquatic Science and Technology

ISSN 2168-9148

2013, Vol. 1, No. 2

Table 2. Result of in-vitro potential test of active compound extract of Kopasanda (C. odorata L.) Leaf

\begin{tabular}{llll}
\hline No. & Treatments & Replication & Bacterial Growth \\
\hline 1 & With kopasanda (C.odorata) extract & 1 & - \\
& & 2 & - \\
2. & Without kopasanda (C.odorata) extract & 1 & + \\
& & 2 & + \\
\hline
\end{tabular}

Particulars: -: No bacterial growth; +: Bacterial growth presented

\subsection{Antibacterial Activity of Kopasanda (C. Odorata L.) Leaf Extract against V. Harveyi}

Result of antibacterial activity of kopasanda (C. odorata L) leaf extract against V. harveyi with different solvents was shown in Figure 3, while the average of inhibitory zone diameter was shown in the histogram form in Figure 4.

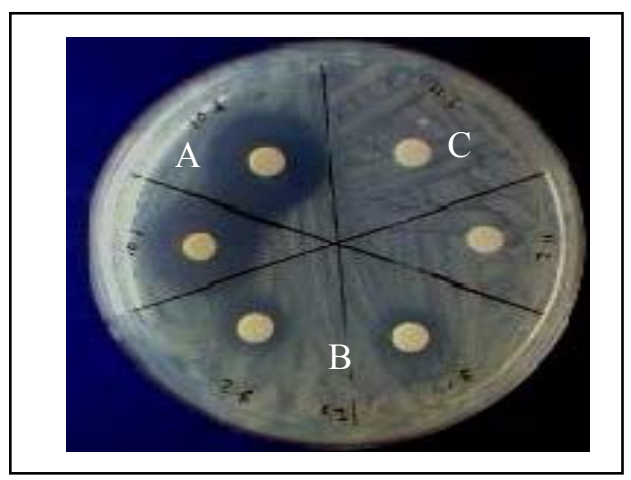

Particulars: A. Methanol solvent; B. Ethyl acetate solvent; C. n-hexane solvent

Figure 4. Result of antibacterial activity of Kopasanda (C. odorata L.) leaf extract

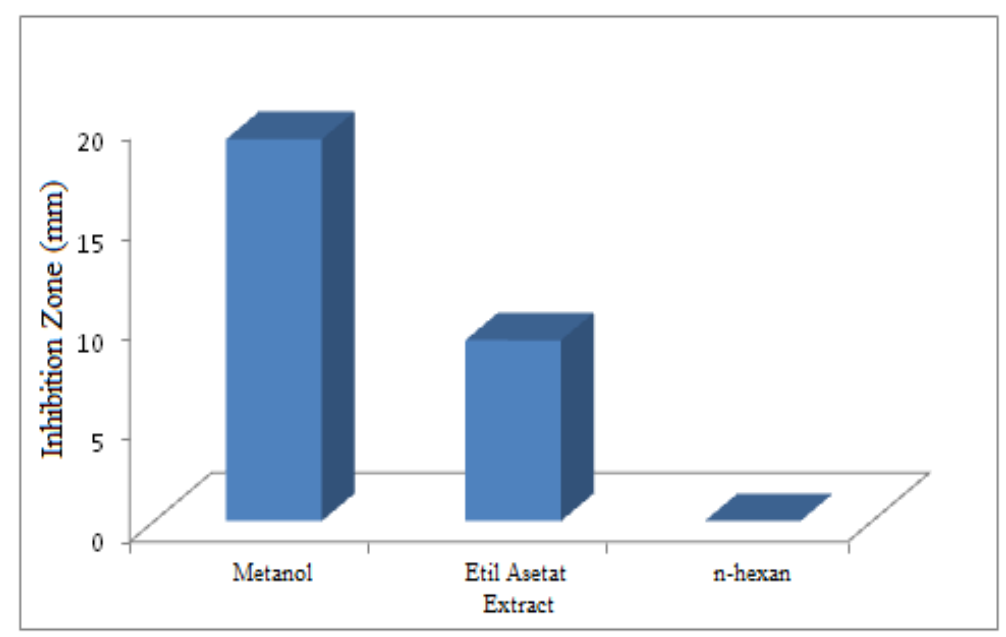

Figure 5. The histogram of inhibition zone ( $\mathrm{mm})$ of each extract 
3.5 Determination of Minimum Inhibitory Concentration (MIC) of the Active Extracts of Kopasanda (C. odorata L)

Result of MIC test of methanol extract of kopasanda (C.odorata L.) leaf was shown in Table 3.

Table 3. Minimum inhibitory concentration (MIC) test of Kopasanda (C. odorata L) extract against $V$. harveyi growth

\begin{tabular}{lll}
\hline No & Extract Doses $(\mathrm{mg} / \mathrm{mL})$ & V. harveyi Growth \\
\hline 1 & 10.000 & - \\
2 & 5.000 & - \\
3 & 2.500 & - \\
4 & 1.250 & - \\
5 & 0.625 & - \\
6 & 0.313 & + \\
7 & 0.156 & + \\
8 & NB + V. Harveyi & + \\
9 & NB & - \\
10 & NB + Kopasanda Extract & - \\
\hline
\end{tabular}

Particulars: + : V. harveyi Growth presented; - : No V. harveyi Growth.

Table 3 indicated that Minimum Inhibitory Concentration rate of kopasanda leaf extract at dose $0,625 \mathrm{mg} / \mathrm{mL}$ was actually able to eliminate $V$. harveyi.

\section{Discussion}

The study showed that kopasanda (C. odorata L.) leaf is useful as an antibacterial compound against $V$. harveyi to eliminate vibriosis in the prawn cultivation. Result of chemical compound identification indicated that phenolic, flavonoid, alkaloid and steroid were presented, similar to result reported by Akinmoladun, et al., (2007), that kopasanda leaf could be developed as natural antibacterial substance.

Phenolic compounds have been shown to disturbed the function of cytoplasm membrane and therefore have been described as antibacterial substances (Volk and Wheeler 1993; Cowan, 1999). At low concentration, phenolic compound can still damage cytoplasm membrane causing the leakage of important metabolite and inactivated bacterial enzymatic system. At high concentration, this compound can damage cytoplasm cell membrane and to precipitate the cell protein. Phenolic compound interact with the component of bacterial cell wall which causes higher permeability of the bacterial cell. This compound also diffuses into the cell slowing and even stopping bacterial growth (Pelczar and Chan, 2005). Moreover, Mori et al., (1987) added that some flavonoid substances such as robinetin, myricetin and epigallocatechin, interfer with the intercalation bond or hydrogen bond at the nucleate acid assembly preventing the activity of DNA and RNA syntheses. Furthermore, steroid compound have been shown to prevent microbial growth by damaging plasma membrane such that the cell cytoplasm was leaked, thus causing cellular death (Putra, 2007). 
Antibacterial activity potential test was carried out to ensure whether methanol extract of kopasanda (C. odorata L.) leaf had ability to prevent $V$. harveyi. Method used in this test was solid dilution method at concentration of $1 \mathrm{mg} / \mathrm{mL}$. The concentration used was consistent with Hoffman (1991) who said that plant extract could be antimicrobial if its concentration of $1 \mathrm{mg} / \mathrm{mL}$ could prevent the growth of $V$. harveyi. Based on the anti bacterial activity potential test in the current study, it was confirmed that kopasanda ( $C$. odorata L) leaf extract prevent the growth of $V$. harveyi. The ability of kopasanda (C.odorata L) leaf extract to prevent $V$. harveyi growth was indeed increasing opportunity that $C$. odorata L. plant could be used as antimicrobial in controlling pathogenic microorganism which caused disease at post-larva stage of prawn. Other research has shown that this leaft exact also restrics the growth Bacillus subtilis, Stapilococcus aureus and Salmonella typhimurium (Vital et al., 2009).

Antibacterial power to prevent microorganism growth was different. The determination of antibacterial power based on Davis Stout Method was producing a classification as followed: Inhibitory zone of $2.0 \mathrm{~cm}$ or more classified as very strong; $1.0-2.0 \mathrm{~cm}$ as strong; $0.5-1.0 \mathrm{~cm}$ as moderate; and smaller than $0.5 \mathrm{~cm}$ as weak. Habsah et al., (2007) asserted that inhibitory zone diameter $\geq 15 \mathrm{~mm}$ was classified as strong, while $10-14.5 \mathrm{~mm}$ was classified as moderate and $<10 \mathrm{~mm}$ was classified as weak. In this study, Strong inhibitory power was shown by methanol extract with $19 \mathrm{~mm}$ inhibition zone, followed by ethyl acetate extract with $9 \mathrm{~mm}$ inhibitory zone. There was no inhibitory zone in $\mathrm{n}$-hexane extract. It meant that bioactive compound that was extracted from $C$. odorata L leaf had antibacterial activity, and could be dissolved into polar and semi-polar solvents, but might not dissolve within non-polar solvent. Therefore, bioactive compound could be extracted with methanol solvent. Review of literature showed that solvents in the extraction would destroy cellular membrane and dissolve pigments (Shidduraju \& Becker, 2003; Ra et al., 1998; Kahkonen et al., 1999). Non-polar solvent, such as n-heksan, was effective to dissolve alkaloid in the alkali form (Jaiarj et al., 1999; Sosa et al., 2010). Semi-polar solvent, such as ethyl acetate, was able to extract phenol and terpenoid compounds, while polar solvent, like methanol, was able to extract quarterner alkaloid compound, phenolic component, carotenoid and tannin (Harborne, 2006).

Based with the result of minimum inhibitory concentration (MIC) test kopasanda (C.odorata L) leaf methanol extract was actively preventing the growth of $V$. harveyi at minimum inhibitory concentration (MIC) of $0,625 \mathrm{mg} / \mathrm{mL}$. According to Aligiannis et al. (2001), MIC below $1.6 \mathrm{mg} / \mathrm{ml}$ indicated strong activity. It meant that kopasanda leaf extract at low dose would have strong antibacterial activity. Therefore, kopasanda (C. odorata L) plant was a promising candidate to be developed as a naturally active compound source for the vibriosis elimination on prawn.

\section{Conclusion}

Considering the result of research on phytochemical analysis and antibacterial activity test of kopasanda leaf extract on Vibrio harveyi, it was concluded that kopasanda (C. odorata L.) leaf was is an effective natural antibacterial because it contained phenolic, steroid, flavonoid, and alkaloid compounds, greatest antibacterial properties and low minimum inhibitory 
concentrations suggested strong antibacterial activity kopasanda leaf extract. Kopasanda (C.odorata L.) plant as the natural antimicrobial to control disease-causing pathogen, $V$. harveyi, especially in the prawn cultivation.

\section{References}

Akinmoladun, A. C., Ibokun And, E. O., \& Dan-Ologe, I. A. (2007). Phytochemical Constituents And Antioxidant Properties of Extracts From the Leaves of Chromolaena odorata. Scientific Research and Essay, 2(6), 191-194.

Aligiannis, N., Kalpotzakis, E., Mitaku, S., \& Chinou, I. B. (2001). Composition and Antimicrobial Activity of the Essential Oils of Two Origanum Species. Journal of Agricultural and Food Chemistry, 40, 4168-4170. http://dx.doi.org/10.1021/jf001494m

Anonymous. (2012). Chromolaena odorata. Retrieved from http://en.wikipedia.org/wiki/Chromolaenaodorata

Arulpriya, P., Lalitha, P., \& Hemalatha, S. (2010). Antimicrobial Testing of The Extracs of Samanea saman (Jacq.) Merr, Der Pharma Chemica, 2(6), 73-83.

Bauer, A. W., Kirby, W. M. M., Sherris, J. C., \& Turck, M. (1966). Antibiotic Susceptibility Testing by a Standardized Single Disc Method. Amer. J. Clin. Pathol., 45, 493-496.

Bourne, D., Webster, L. H. N., Payne, M., Skinderse, M., Givskov, M., \& Hall, M. (2007). Microbiological Aspects of Phyllosoma Rearing of the Ornate Rock Lobster Panulirus ornatus. Aquaculture, 268, 274-287. http://dx.doi.org/10.1016/j.aquaculture.2007.04.067

Brown, J. H. (1989). Antibiotics, their use and abuse in aquaculture. Aquaculture, 2, 34-43.

Cowan, M. M. (1999). Plants Product as Antimicrobial agent. Clinical Microbiology review, 12(4), 564-582.

Cushnie, T. P. T., \& Lamb, A. J. (2005). Antimicrobial Activity of Flavonoids. Review. International Journal of Antimicrobial Agent, 26, 343-356. http://dx.doi.org/10.1016/j.ijantimicag.2005.09.002

Defoirdt, T., Boon, N., Sorgeloos, P., Verstraete, W., \& Bossier, P. (2007). Alternatives to Antibiotics to Control Bacterial infections: Luminescent Vibriosis in Aquaculture as an Example Trends in Biotehnology, 25(10), 472-479.

Diggles, B. K., Moss, G. A., Carson, J., \& Anderson, C. D. (2000). Luminous vibriosis in rock lobster Jasus verreauxi (Decapoda: Palinuridae) phyllosoma larvae associated with infection by Vibrio harveyi. Dis. Aquat. Organ., 43, 127-137. http://dx.doi.org/10.3354/dao043127

Egwaikhide, P. A., \& Gimba, C. E. (2007). Analysis of The Phytocemical Conten t and Antimicrobial Activity of Plectranthus gladulosis Whole plant, Middle-East. Journal of Scientific Research, 2(3-4), 135-138.

Fattah, H. (2008). Standardization of Production Technology and Product Quality Tiger Shrimp Aquaculture (P.monodon) In Organic Based on Market Conditions UNI EROPA. 
DP2M DIKTI.

Habsah, M. Z. M. R., Khozirah, S., Jalifah, L., Lajis, N. H., \& Ali, A. M. (2007). DPPH Free Radical-Scavenging and Antibacterial activities of Methanolic Extracts of Aaptos sp. (Marine sponge) in $12^{\text {th }}$ Asian Chemical Congress (12ACC) in Conjunction with International Symposium on Natural Product and Medical Chemistry, 23-25 August, Kuala Lumpur, Malaysia.

Harborne, J. B. (2006). Phytochemical Methods Simplified Method Wizard Analyzing Plant. (Padmawinata, K and I, Soediro, Trans.). Bandung: Publisher ITB.

IAEA. (2000). Quntification of Tannin in Tree Foliage FOA/IAEA, Viena.

Isnansetyo, A. T., Setyowati, E. P., \& Anshory, H. H. (2009). In vitro antibacterial activity of methanol extract of a sponge, Geodia sp. Against oxytetracyclin-resistent Vibrio harveyii and its toxicity. J. Biol. Sci, 9, 224-230. http://dx.doi.org/10.3923/jbs.2009.224.230

Jagessar, R. C., \& Cox, M. (2010). Phytocemical Screening of The $\mathrm{CHCl}_{3}, \mathrm{CH}_{3} \mathrm{CH}_{2} \mathrm{OH}$ Extract of Stems Twigs, Roots and Bark of Conocarpus erectus L. Int. Acad. Research, 2(5), $37-45$.

Jaiarj, P., Khoohaswan, P., Wongkrajang, Y., Peungvicha, P., Suriyawong, P., Saraya, M. L. S., \& Ruangsomboon, O. (1999). Anticough and antimicrobial activities of Psidium guajava Linn. leaf extract. Journal Of Ethnopharmacology, 67, 203-212. http://dx.doi.org/10.1016/S0378-8741(99)00022-7

Jivaranichpaisal, P. T., Miyasaki, T., \& Limsuwan, C. (1994). Histopathology, biochemistry and pathogenicity of Vibrio harveyi infecting black tiger prawn Penaeus mondon. J. Aquat. Ann. Health, 6, 27-35. http://dx.doi.org/10.1577/1548-8667(1994)006<0027:HBAPOV>2.3.CO;2

Kähkönen, M. P., Hopia, A. I., Vuorela, H. J., Rauha, J. P., Pihlaja, K., Kujala, T. S., \& Heinonen, M. (1999). Antioxidant Activity of Plant Extracts Containing Phenolic Compounds. Journal of Agricultural and . Food Chemistry, 47(10), 3954-3962. http://dx.doi.org/10.1021/jf9901461

Karuna Sagar, I., Pai, R., \& Malathi, G. R. (1994). Mass mortality of Penaeus monodon larvae due to antibiotic resistant Vibrio harveyi infection. Aquaculture, 128, 203-209. http://dx.doi.org/10.1016/0044-8486(94)90309-3

Kodriah, I. A., Susianingsih, E., Sukenda, M., \& Yuhana, E. H. (2011). Patogenitas bakteri Vibrio harveyi Yang diisolasi bahasa Dari KBLI berbeda. Jurnal Akuakultur Indonesia (Inprogres).

Lavilla-Pitogo, C. R., Albright, L. J., Poner, M. C., \& Sunaz, N. A. (1992). Studies on the sources of luminescent Vibrio harveyi in Penaeus monodon hatcheries. In I. M. Shariff, R. P. Subasinghe, \& J. R. Arthur (Eds.), Diseases in Asian Aquaculture I. Fish Healt Section (pp. 157-164). Asian Fisheries Society, Manila, Philippines.

Liu, P. C., Lee, K. K., Yii, K. C., Kou, G. H., \& Chen, S. N. (1996). Isolation of Vibrio 
harveyi from diseased kuruma prawns Penaeus japonicus. Curr. Microbiol., 33, 129-132. http://dx.doi.org/10.1007/s002849900087

Makkar, P. R. D., \& Singh, B. (1988). Determination of Both Tannin and Protein Complex. J. Agric. Food Chem, 36(3), 523-525. http://dx.doi.org/10.1021/jf00081a600

Mariyono, A. W., \& Sutomo. (2002). Techniques flaming shrimp disease control through population control bacteria in the laboratory. Bulletin of Agricultural Engineering 7(1), $25-27$.

Mori, A., Nishino, C., Enoki, N., \& Tawata, S. (1987). Antibacterial Activity and Mode of action of Plant Flavonoids againt Proteus vulgaris and Staphylococcus auratus. Phytochemistry, 26, 2231-2234. http://dx.doi.org/10.1016/S0031-9422(00)84689-0

O’Brien, B. A., Bonicamp, J. M., \& Jones, D. W. (1982). Diffrentiation of Amphetamine and its major Halucinogenic DerivatesUsing Thin-Layer Chromatography. J. And. Toxicol. 6, 143-147.

Pelczar, \& Chan. (1988). Dasar-dasar Mikrobiologi I. (Hadioetomo RS, Imas T, Tjitrosomo SS, Angka SL. Jakarta, Trans.). Penerbit Universitas Indonesia, 508 hal.

Putra, I. N. K. (2007). Study Power Antimicrobial Preservatives Plant Extract Multiple Materials destroyer Nira Nira Against Microbes and Gynecology Actively compounds. (Unpublished Doctoral Dissertation). University of Brawijaya Malang.

Ra, K. S., Suh, H. J., Chung, S. H., \& Son, J. Y. (1998). Antioxidant Activity of Solvent Extract From Onion Skin. Korean Journal of Food Science and Technology, 29(3), 595-600.

Robertson, P. A. W., Calderon, J., Carrera, L., Stark, J. R., Zherdmant, M., \& Austin, B. (1998). Experimental Vibrio harveyi infections in Penaeus vannamei larvae. Dis. Aquat. Organ., 32, 151-155. http://dx.doi.org/10.3354/dao032151

Rosmiati, H. M., \& Tengku, S. T. M. (2011). Biological Activities of Methanolic Extracts of Several Sponge Species. UMTAS 2011. Empowering Science, Technology and Innovation Towards a Better Tomorrow Institute of Marine Biotechnology, Universiti Malaysia Terengganu, 21030 Kuala Terengganu, Malaysia.

Siddhuraju, P., \& Becker, K. (2003). Antioxidant Properties of Various Solvent Extracts of Total Phenolic Constituents from Three Different Agroclimatic Origins of Drumstick Tree (Moringa oleiferaLam.) Leaves. Journal Of Agricultural and Food Chemistry, 51(8), 2144-2155. http://dx.doi.org/10.1021/jf020444+

Sosa, R. A., Franco, M. G. G., Dávila, A. C., Munoz, J. V. T., \& Moorill, G. V. N. (2010). Extracts of Mexican Oregano (Lippia berlandieri Schauer) with Antioxidant and Antimicrobial Activity. Food and Bioprocess Technology, 3(3), 434-440. http://dx.doi.org/10.1007/s1 1947-008-0085-7

Soto-Rodriguez, S. A., Roque, A., Lizarraga-Partida, M. L., Guerra-Flores, A. L., \& Gomez-Gil, B. (2003). Virulence of luminous vibrios to Artemia franciscana nauplii. Dis. 
Aquat. Organ., 53, 231-240. http://dx.doi.org/10.3354/dao053231

Sunaryanto, A., \& Mariam, A. (1986). Occurrence of Pathogenic Bacteria Causing Luminescent in Penaeid Larvae in Indonesia Hatcheries. Bull. Brackish Water Aqua. Dev. Cent. 8(2), 64-70.

Suryati, E. S., \& Gunarto. (2001). Crop Utilization Kopasanda (Euphatorium inulifolium HBK) as a bactericide in shrimp aquaculture ponds. Proceedings of the Seminar on Regional Development of Agricultural Technology Specific Locations in Central Sulawesi 2001.

Vital P. G., \& Rivera, W. L. (2009). Antimicrobial Activity and Cytotoxicity of Chromolaena odorata (L.f.) King and Robinson and Uncaria perrottetii (A. Rich) Merr. Extracts. Journal of Medicinal Plants Research, 3(7), 511-518.

Volk, W. A., \& Wheeler. (1993). Basic Microbiology (p. 390). Miscellaneous: Markham Edition V publisher. Jakarta.

Wibowo, M. A., Aulanni'am, M. S., \& Rahman, F. (2008). Phytochemical Screening of Methanol Fraction Diethyl n- Hexane Etern Kesum Leaf Extract (Polygonun minus). Proceedings of National Seminar on Research of Biological Sciences, UB, July 24, 2008.

\section{Copyright Disclaimer}

Copyright reserved by the author(s).

This article is an open-access article distributed under the terms and conditions of the Creative Commons Attribution license (http://creativecommons.org/licenses/by/3.0/). 